\title{
Single Ended Primary Inductor Converter for Delta Conversion of PV Systems
}

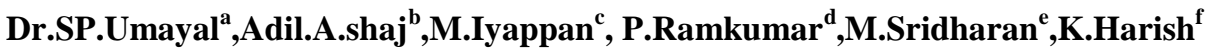 \\ ${ }^{a}$ Professor, EEE,PSN college of Engineering and Technology, Tirunelveli. \\ $\mathrm{b}, \mathrm{c}, \mathrm{d}, \mathrm{e}, \mathrm{f}$ Students EEE, PSN college of Engineering and Technology, Tirunelveli. \\ ${ }^{a}$ Corresponding author mail id: umayalbabu@gmail.com
}

Article History: Received: 10 November 2020; Revised 12 January 2021 Accepted: 27 January 2021; Published online: 5 April 2021

\begin{abstract}
Electrical Energy can be generated by Photovoltaic (PV) systems. To achieve desired power range PV modules are connected both in series and parallel. There will be a difference between output power between PV cells, modules due to temporary shading, pollution or spread in cell behaviour. PV output power will be reduced due to this. In this paper in order to get the same output power during such condition delta conversion concept is introduced with the help of a DC/DC SEPIC converter. This is a converter capable of averaging out the difference existing in output power between PV cells, modules existing in PV system. The converter is simulated in MATLAB software and the results obtained are compared with the prototype hardware results.
\end{abstract}

Keywords: Photovoltaic, DC/DC converter, Delta Conversion, Single ended Primary Inductor Converter (SEPIC).

\section{Introduction}

Conventional energy sources leads to decaying the environment, global warming, and fuel price hikes. Hence there is a demand for renewable energy sources. Solar energy is non-polluting source of renewable energy available in plenty [1]. India has long days of sunshine. Electricity can be generated using solar energy. Solar Photovoltaic cells converts solar radiations into electricity. SPV can be used for applications like water pumping, street lighting, domestic lighting, water heating, railway signals etc. Radiation of sun is converter into electricity by photovoltaic cell. Current is driven in the external load by means of the voltage output of PV cell due to electric field in it. Depending on the required output power and voltage 10-12 PV cells is placed in series in a string. PV modules are formed by connecting the strings in series and parallel. PV modules are available in different rating in the market. PV output depends on the light intensity. It is a current delivery device. The output power of the PV system decreases by $30 \%$, when it is shaded $10 \%$ due to practical cases[2]-[10]. PV array are formed by connecting PV cells in series and parallel. When connected in series the voltage output of the module increases and during parallel connection current increases. In order to maximize the power output for a PV module maximum power point tracking of the system is necessary.MPP depends upon irradiance condition, temperature and load connected [11]-[12]. The decreased output voltage of a PV module can be improved by DC/DC delta converter. In this work SEPIC converter is used as a delta converter. In [13] S.Muthubalaji et.al proposed an enhanced model for PV System considering various weather conditions.

\section{Working Of Sepic As A Delta}

\section{Conversion}

SEPIC converter can operate from an input voltage which is more than or less than the regulated output voltage. In spite of minimal number of active components SEPIC converter can function in both buck and boost mode. A simple converter can regulate the output of the SEPIC converter which has low noise 


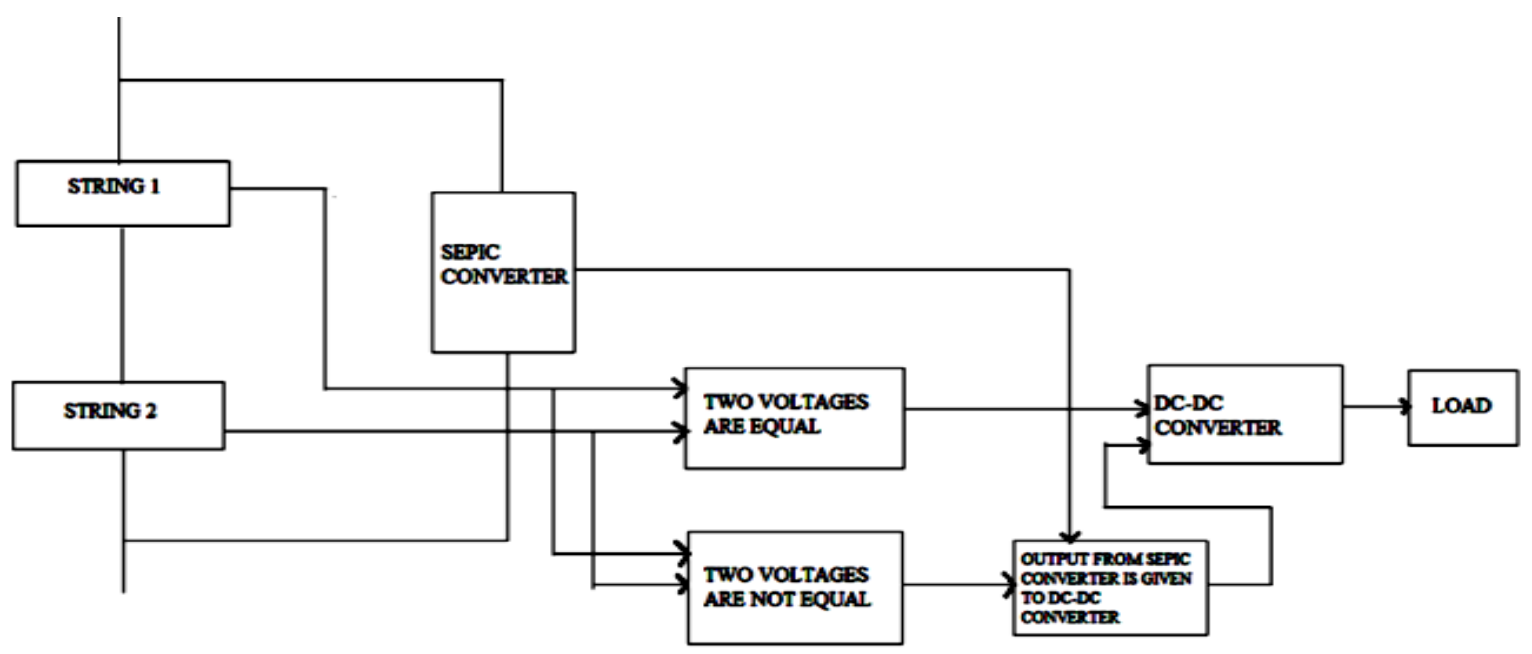

Fig. 1. Delta conversion concept

\section{A. Delta conversion concept}

SEPIC converter is used as a Delta Converter. Only when difference between two strings exists, the delta conversion takes place i.e., the SEPIC converter is active, otherwise it is in OFF state. Therefore, low cost and low efficiency converter can be used. Also, here one converter for two strings is used compared to conventional one, where each string consists of its own DC-DC Converter. When the voltage of two strings are equal the voltage is fed directly into the DC-DC boost converter which drives the load.

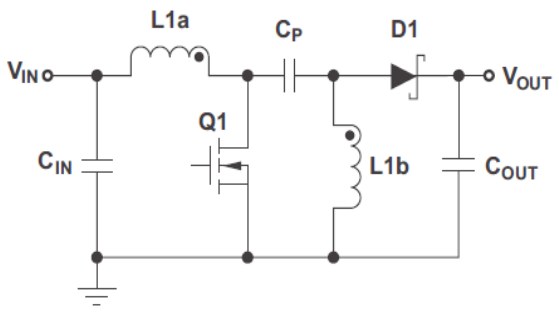

Fig. 2. Schematic diagram of SEPIC Converter

During steady state operation of SEPIC converter the voltage across the capacitor $\mathrm{C}_{\mathrm{in}}$ will be equal to $\mathrm{V}_{\text {in. }}$. The average current across the capacitor $\mathrm{C}_{\mathrm{IN}}$ is zero. Direct current (DC) is blocked by the capacitor. Load is supplied by the inductor $L_{1 b}$. Therefore, the average load current will be same as average current through inductor $L_{1 b}$ and it is independent of input voltage.

$$
\mathrm{V}_{\mathrm{L} 1 \mathrm{a}}=-\mathrm{V}_{\mathrm{L} 1 \mathrm{~b}} \text {. }
$$

Assuming the polarity of the winding as correct and the mutual inductance among the winding is zero, the voltage is of same magnitude both inductors is wound on the same core.

The average currents can be summed as follows:

$$
I_{D 1}=I_{L 1 a}-I_{L 1 b}
$$

SEPIC converter works in continuous conduction mode so the current in the inductor $\mathrm{L}_{1 \mathrm{a}}$ never falls to zero.

\section{B Mode1: when q1 is on}

When $Q_{1}$ is turned on (shown in fig 3), current in $I_{L 1 a}$ increases and the current in the inductor $I_{L 1 b}$ rises in the reverse direction. The input source supplies the energy. Capacitor voltage $C_{\text {in }}$ will be equal to $V_{\text {in }}$ when the switch Q1 is closed. Voltage across the inductor $L_{1 b}$ will be $-V_{i n}$. Capacitor $C_{i n}$ supplies the energy to $L_{1 b}$ which increases the current $\mathrm{I}_{\mathrm{L} 1 \mathrm{~b}}$ through the inductor. 


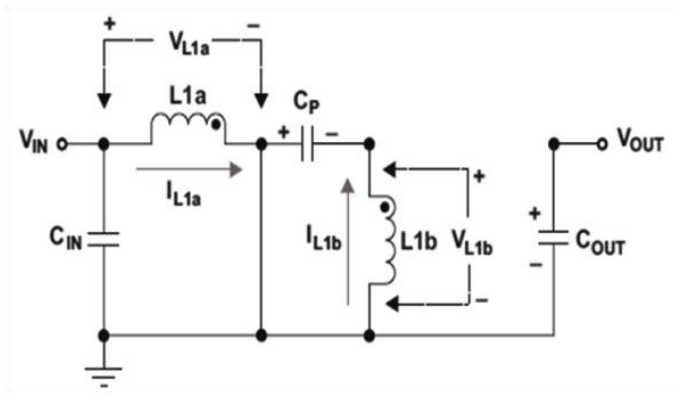

Fig. 3. SEPIC Converter mode $1 \mathrm{Q}_{1}$ on

\section{Mode 2: when q1 is off}

In mode $2 Q_{1}$ is off, (shown in fig 4 ) current through the capacitor $C_{p}$ will be equal to the inductor current $I_{L 1 a}$. Current through the inductor $\mathrm{I}_{\mathrm{L} 1 \mathrm{~b}}$ will flow in negative direction which gets added up with $\mathrm{I}_{\mathrm{L} 1 \mathrm{a}}$ and increases the load current. Applying KCL $\mathrm{I}_{\mathrm{D} 1}=\mathrm{I}_{\mathrm{Cp}}-\mathrm{I}_{\mathrm{L} 1 \mathrm{~b}}$. So when switch $\mathrm{Q}_{1}$ is in off condition load is supplied by both inductor $\mathrm{L}_{1 \mathrm{a}}$ and $\mathrm{L}_{1 \mathrm{~b}}$. $\mathrm{L}_{1 \mathrm{a}}$ charges $\mathrm{C}_{\mathrm{p}}$ during $\mathrm{Q}_{1}$ off mode which in turn charges $\mathrm{L}_{1 \mathrm{~b}}$ during $\mathrm{Q}_{1}$ on mode.

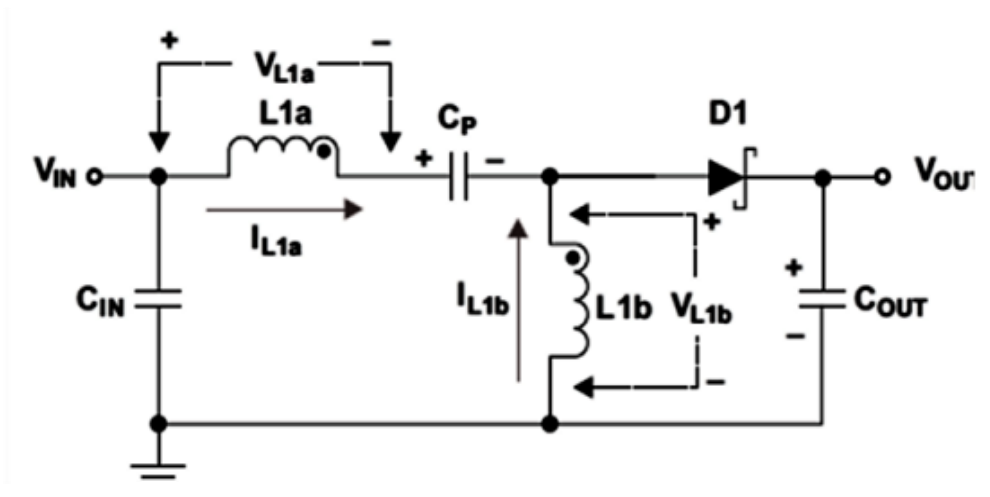

Fig. 4. SEPIC Converter mode $2 Q_{1}$ off

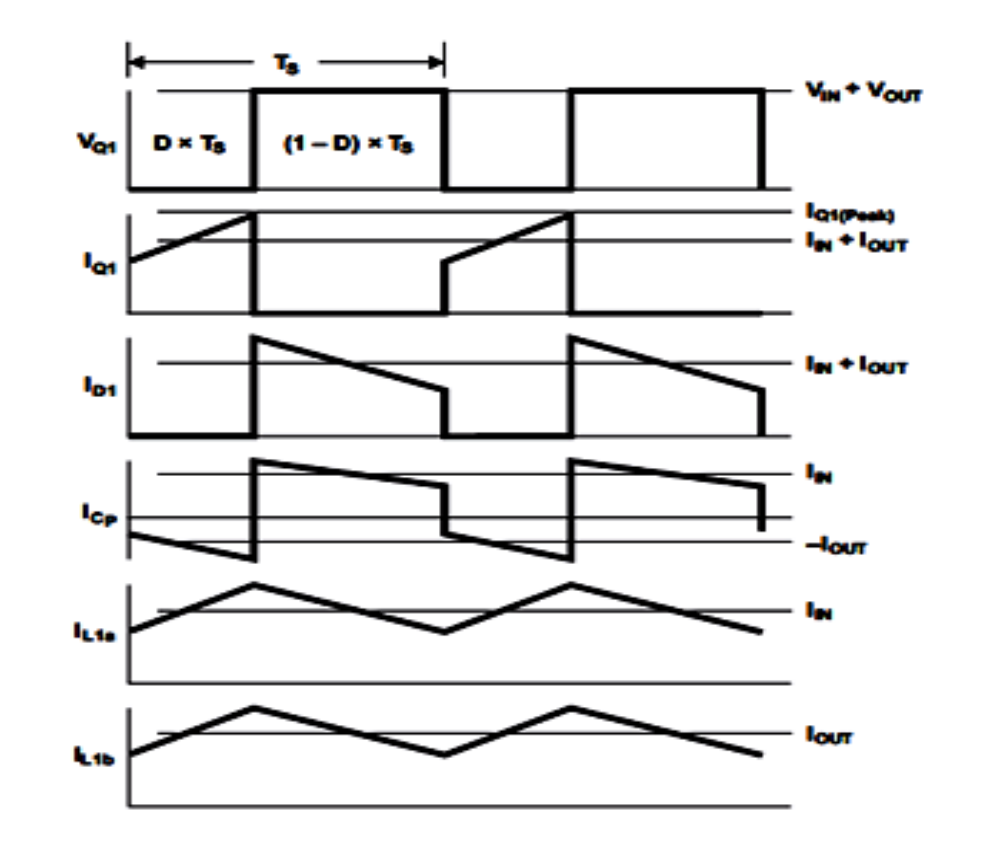

Fig. 5. Waveform of SEPIC Converter

A non polarized capacitor should be used, as the voltage across the capacitor $\mathrm{C}_{\mathrm{p}}$ reverse direction every cycle. Capacitor $\mathrm{C}_{\mathrm{p}}$ and inductor $\mathrm{L}_{1 \mathrm{~b}}$ helps the SEPIC converter to operate both in buck and boost mode. The operation of converter in buck or boost mode is determined by its duty cycle. The output voltage $\mathrm{V}_{0}$ is $\mathrm{V}_{\text {out }}-\mathrm{V}_{\text {in }}$. The average 
voltage across $C_{p}$ is $V_{\text {in }}$. When $V_{\text {out }}$ is greater than twice $V_{\text {in }}$ the output voltage of the converter $V_{0}$ will be greater than the input voltage and converter voltage will be less than input voltage when $V_{\text {out }}$ is less than twice $V_{\text {in }}$.

Damage to the inductors can be prevented by making use of extremely fast switching diodes like schottky diodes which avoids generation of high voltage spikes across the inductor. Converter efficiency can be increased and the converter ripple can be reduced by making use of inductors with low series resistance which allows less energy to be dissipated as heat. This helps to transfer more input power to load. Capacitance with low ESR should be used for $\mathrm{C}_{\mathrm{p}}$ and $\mathrm{C}_{\mathrm{in}}$ so as to prevent heat built up in the circuit and reduce ripple in the circuit due to change in direction of current frequently in it.

\section{Simulation Circuit}

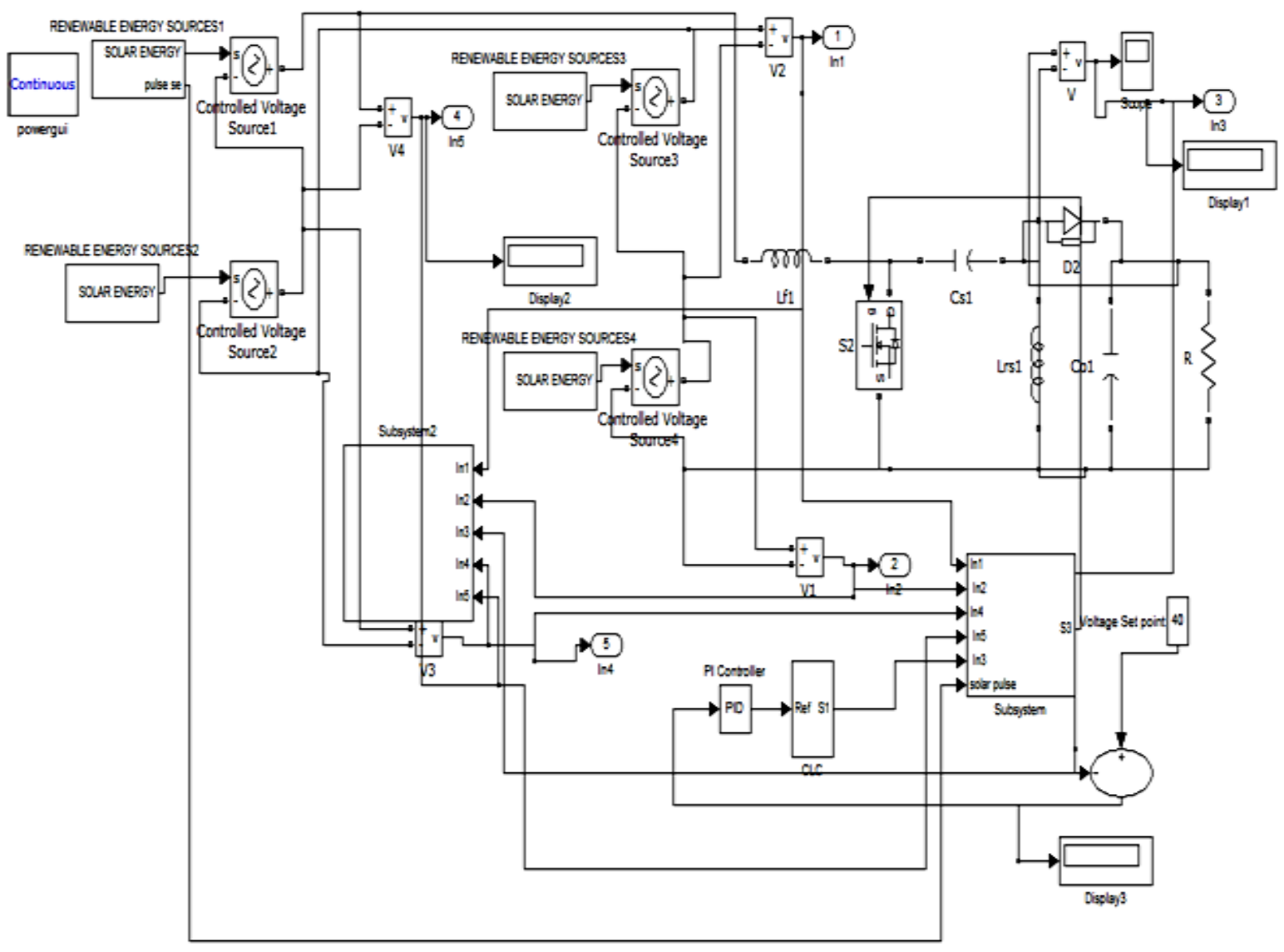

Fig .6. Simulation circuit

Simulation is performed, and the outputs are compared for equal and unequal voltages.

CASE1: Different voltage: $\mathrm{V}_{1}=9 \mathrm{~V} \& \mathrm{~V}_{2}=4 \mathrm{~V}$.

CASE2: Same voltage: $\mathrm{V}_{1}=\mathrm{V}_{2}=9 \mathrm{~V}$. 


\section{A. Case1: Results for different input voltage}

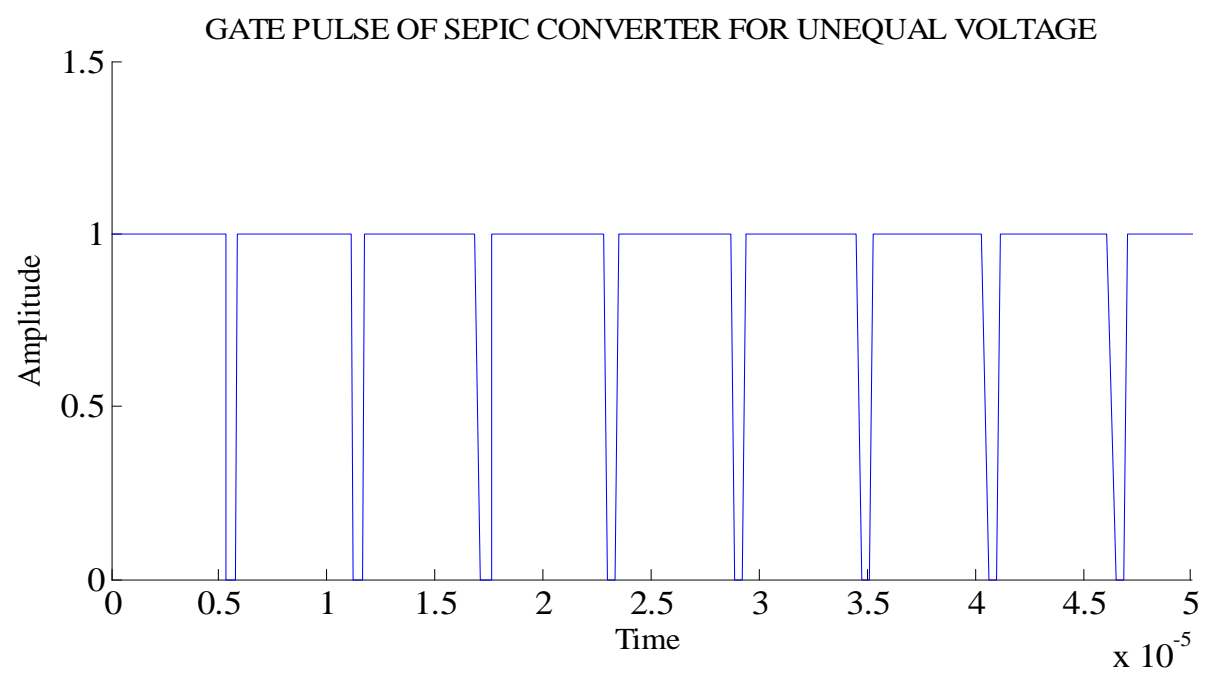

Fig . 7. Case 1 SEPIC Converter Gate Pulse

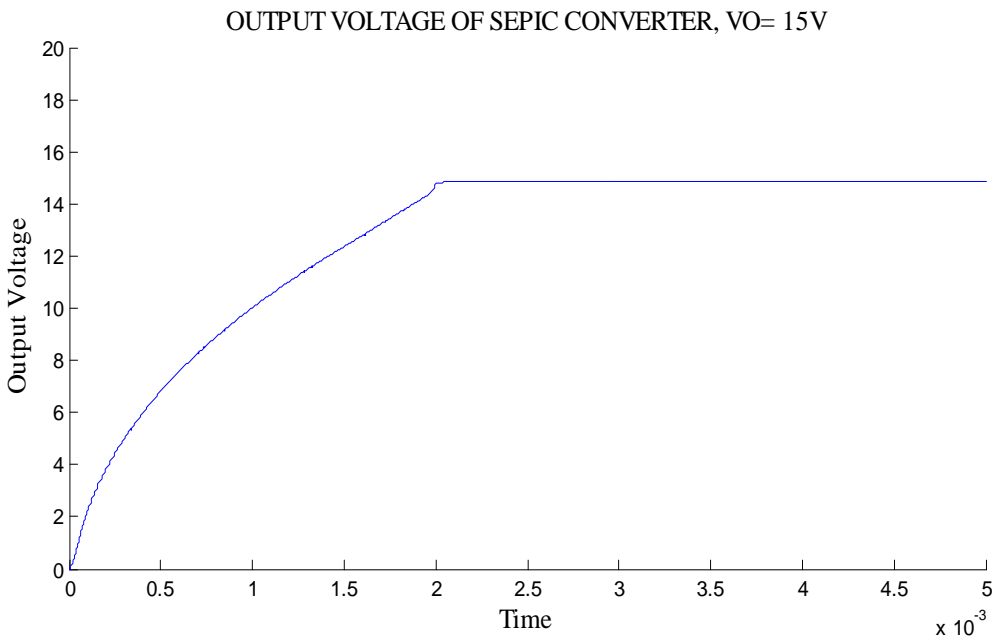

Fig. 8. Case1 SEPIC Converter voltage output

The Fig. 8 shows Case1 SEPIC converter output voltage. It maintains the output voltage approximately at $15 \mathrm{~V}$. This output voltage is given to boost converter. The Boost converter output voltage is $31.96 \mathrm{Vwhich}$ is shown in Fig. 9. The Fig.10 shows the current output from boost converter which is 3.1A. 


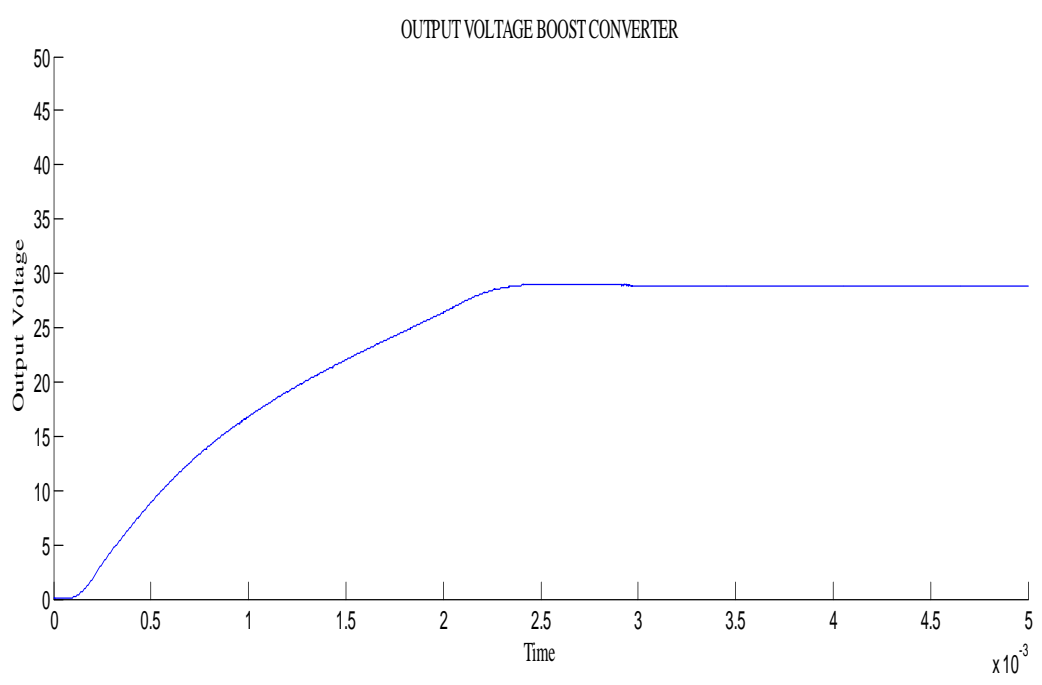

Fig.9. Case 1 BOOST Converter voltage output

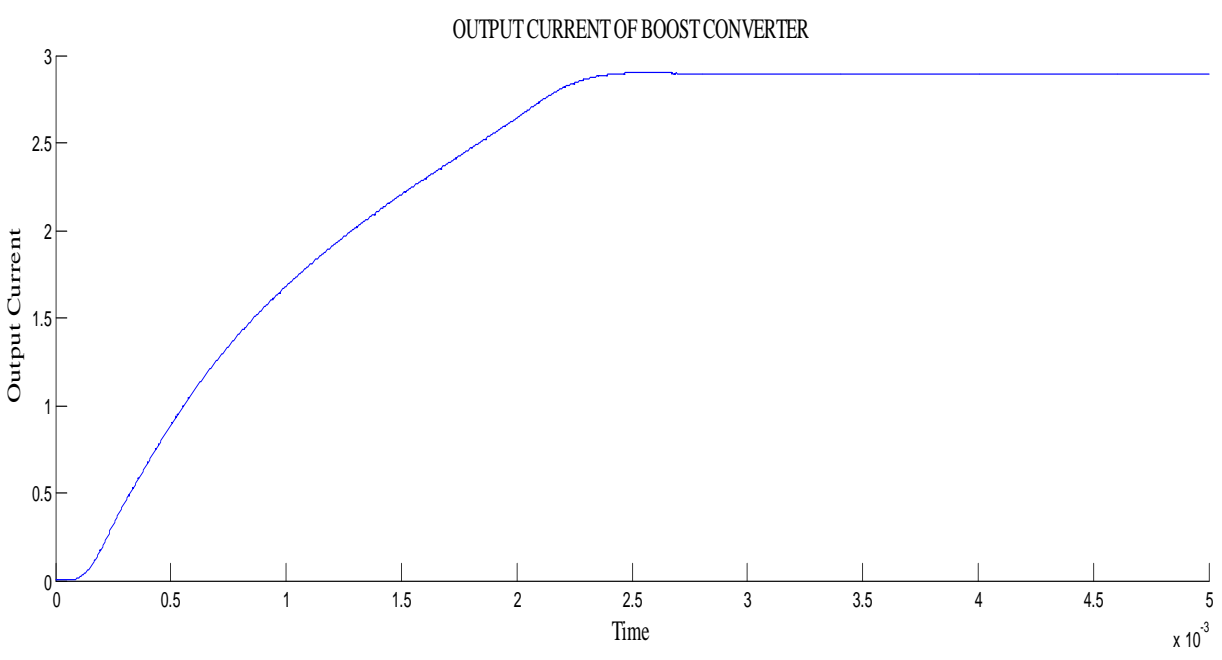

Fig.10. Case 1 BOOST Converter current output

\section{B. Case2: Results for equal input voltage}

\section{OUTPUTVOLAGEOF SEPPCFOREQULALIPUTVOLTAGE}

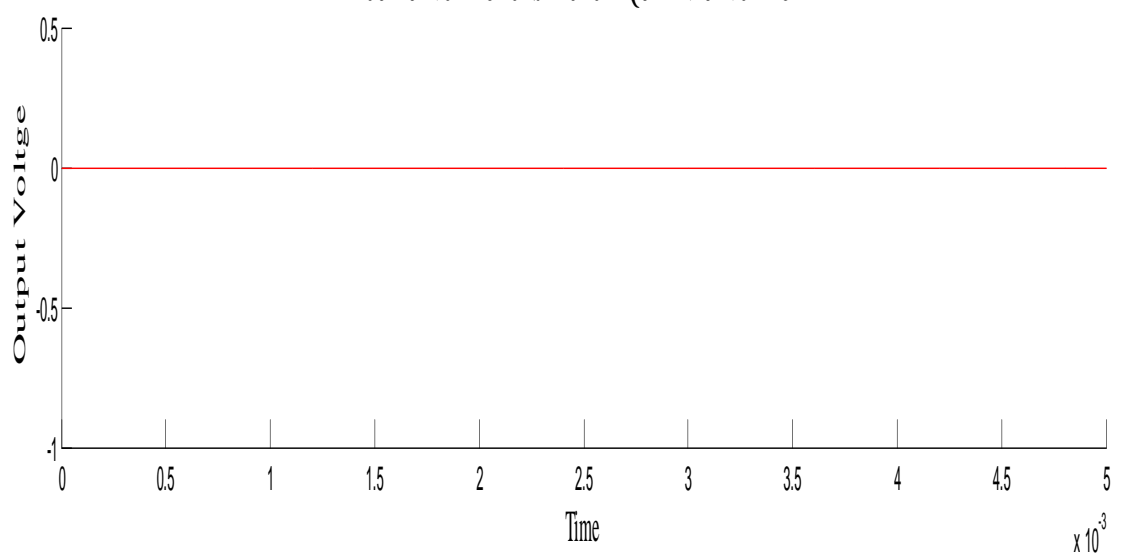

Fig. 11. Case 2 SEPIC Converter Gate Pulse

Fig. 11 shows zero output from SEPIC converter. When two input voltage from PV modules are equal the micro controller does not generate any pulse for the SEPIC converter. The converter will be idle and the PV output is directly fed to the boost converter in this case. 


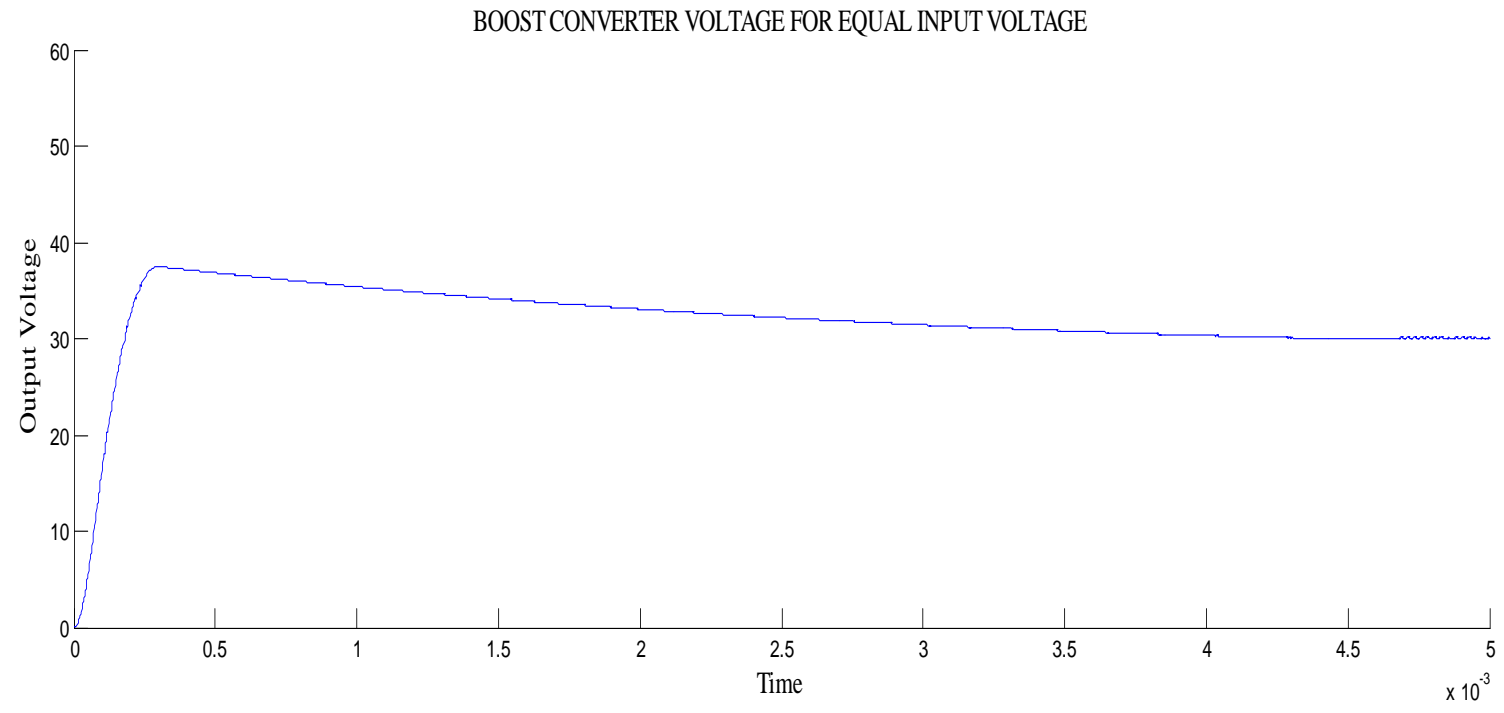

Fig. 12. Case 2 BOOST Converter voltage output

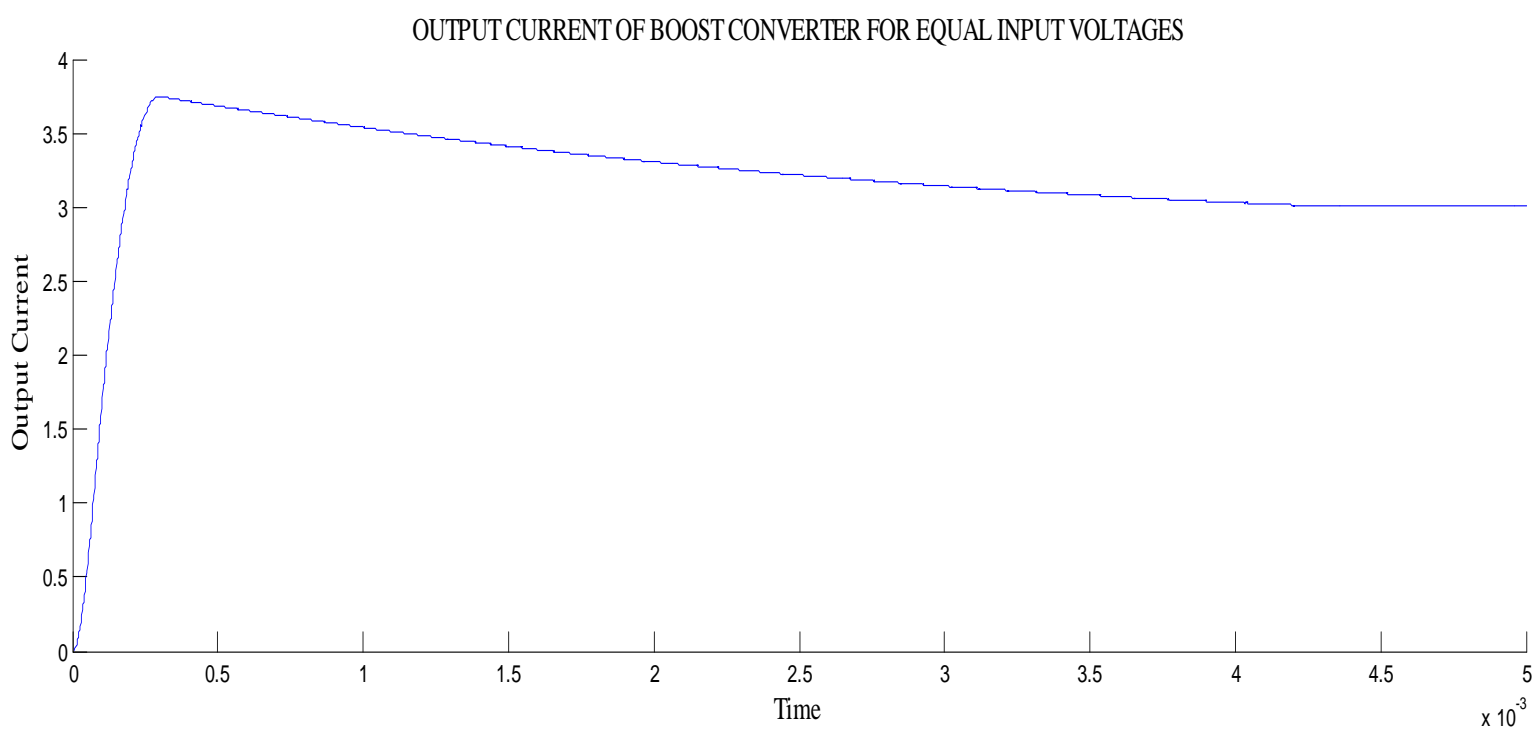

Fig .13. Case 2 BOOST Converter current output

The Fig.12 shows the output voltage of boost converter for case2. This output voltage is used to supply the resistive load. The output voltage obtained by simulation is $34.32 \mathrm{~V}$. Fig. 13 shows the output current of BOOST converter when voltages are equal is 3.4A. For equal input voltage SEPIC converter is in OFF condition. The results are compared in table 1

Table 1Simulation results

\begin{tabular}{|l|l|l|}
\hline Cases & $\begin{array}{l}\text { PV MODULE } \\
\text { OUTPUT } \\
\text { VOLTAGE }\end{array}$ & $\begin{array}{l}\text { OUTPUT } \\
\text { VOLTAGE } \\
\text { FROM SEPIC } \\
\text { CONVERTER }\end{array}$ \\
\hline $\begin{array}{l}\text { Different } \\
\text { voltage }\end{array}$ & $\mathrm{V}_{1}=9 \mathrm{~V} \& \mathrm{~V}_{2}=4 \mathrm{~V}$ & $15.0 \mathrm{~V}$ \\
\hline $\begin{array}{l}\text { Equal } \\
\text { Voltage }\end{array}$ & $\mathrm{V}_{1}=\mathrm{V}_{2}=9 \mathrm{~V}$ & $0 \mathrm{~V}$ \\
\hline
\end{tabular}

Table 2Comparison of different input voltages 
C. Hardware circuit

\begin{tabular}{|l|l|l|l|l|}
\hline \multicolumn{2}{|l|}{ VOLTAGE } & \multicolumn{3}{l|}{ SIMULATION } \\
\hline V1 & V2 & $\begin{array}{l}\text { Output of } \\
\text { SEPIC }\end{array}$ & $\begin{array}{l}\text { Output } \\
\text { Voltage of } \\
\text { Boost }\end{array}$ & $\begin{array}{l}\text { Output } \\
\text { Current of } \\
\text { Boost }\end{array}$ \\
\hline 9 & 9 & $\begin{array}{l}\text { No } \\
\text { operation }\end{array}$ & $34.32 \mathrm{~V}$ & $3.4 \mathrm{~A}$ \\
\hline 2 & 9 & $15 \mathrm{~V}$ & $31.85 \mathrm{~V}$ & $3.1 \mathrm{~A}$ \\
\hline 9 & 4 & $15 \mathrm{~V}$ & $31.96 \mathrm{~V}$ & $3.1 \mathrm{~A}$ \\
\hline 5 & 9 & $15 \mathrm{~V}$ & $31.99 \mathrm{~V}$ & $3.1 \mathrm{~A}$ \\
\hline
\end{tabular}

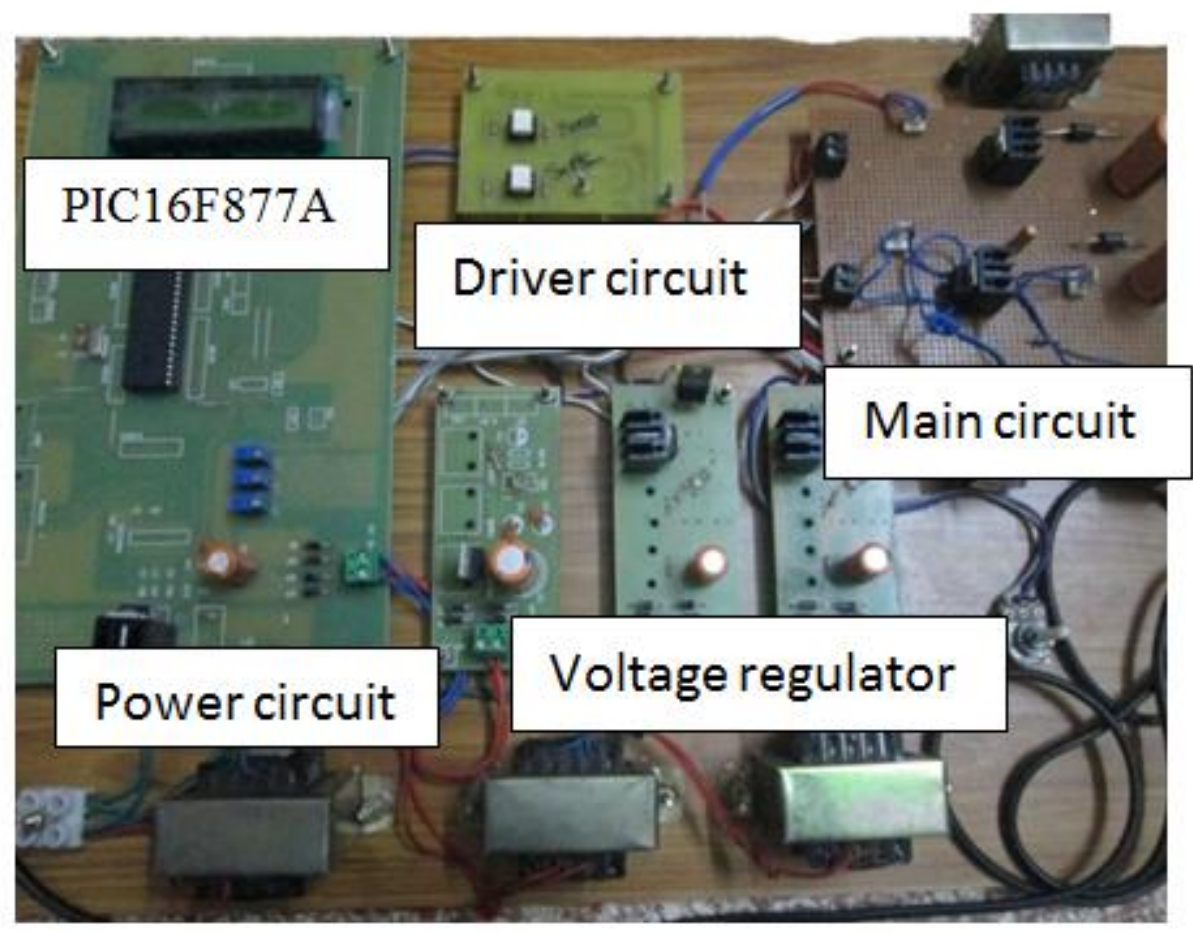

Fig. 14. Hardware circuit

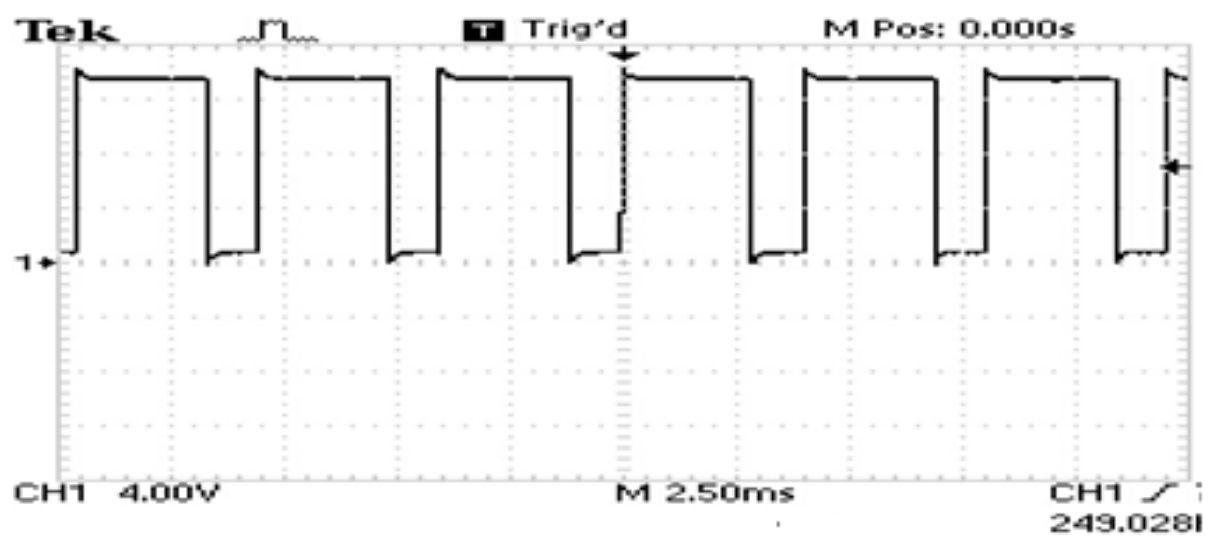

Fig. 15. Case1 DSO gate pulse output from SEPIC converter 


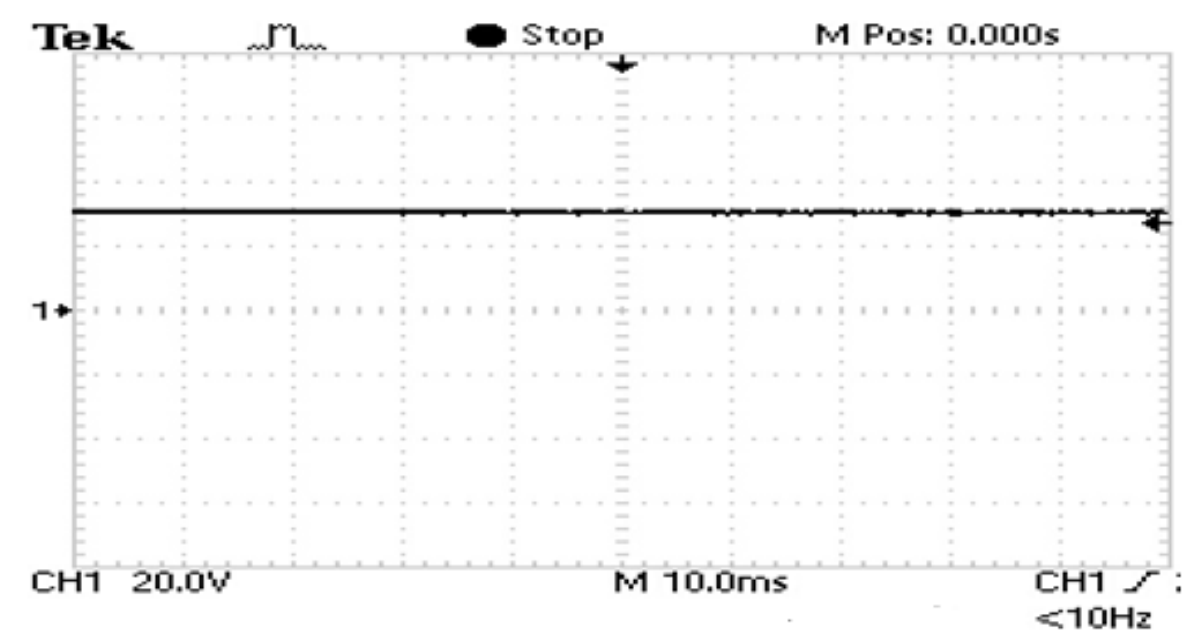

Fig. 16. Case1 DSO Voltage output of SEPIC Converter

Fig.14 shows the hardware circuit. The Fig 15 shows Case 1 gate pulse given to SEPIC converter. The results are taken from the DSO. This pulses indicates that the converter is in active stage when two voltages are different.

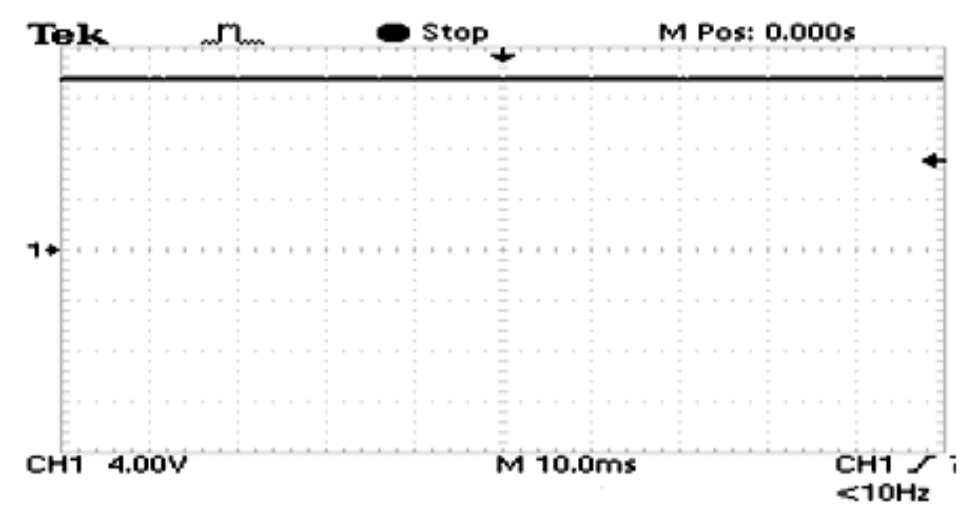

Fig. 17. Case1 DSO Voltage output of Boost Converter

The Fig. 17 shows Case1 voltage output of Boost converter which is $28.9 \mathrm{~V}$ obtained from hardware circuit using DSO. This output voltage is used to supply the load.

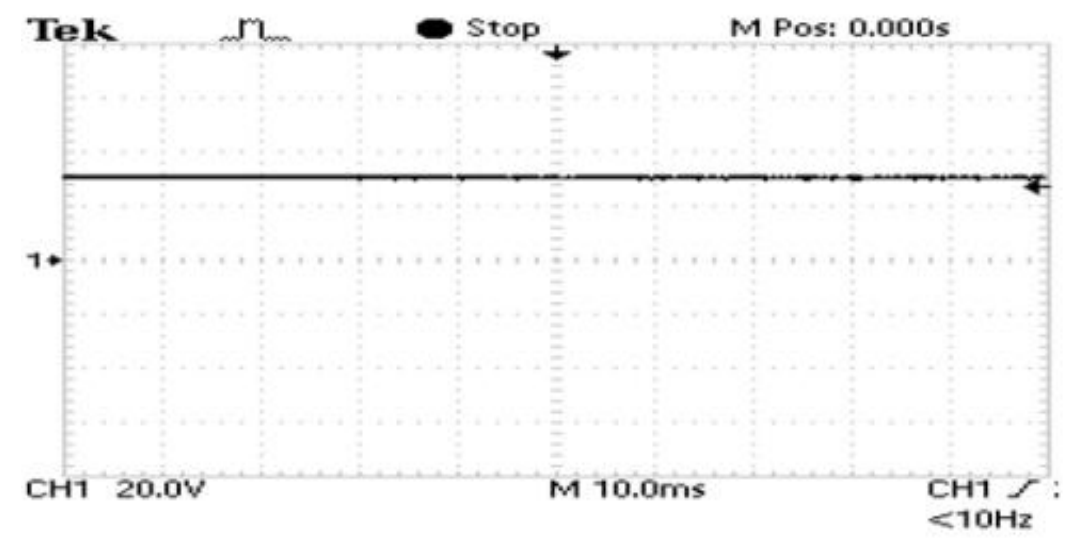

Fig. 18. Case2 DSO Voltage output of BOOST Converter

The figure 18 shows Case 2 hardware output voltage of Boost converter obtained from DSO which is $27.8 \mathrm{~V}$. 


\begin{tabular}{|c|c|c|c|c|c|}
\hline \multicolumn{2}{|c|}{ VOLTAGE } & \multicolumn{2}{c|}{ SIMULATION OUTPUT } & \multicolumn{2}{c|}{ HARDWARE OUTPUT } \\
\hline$V_{1}$ & $\mathbf{V}_{\mathbf{2}}$ & $\begin{array}{c}\text { Output of } \\
\text { SEPIC(V) }\end{array}$ & $\begin{array}{c}\text { Output of } \\
\text { BOOST } \\
(\text { V) }\end{array}$ & $\begin{array}{c}\text { 0utput of } \\
\text { SEPIC(V) }\end{array}$ & $\begin{array}{c}\text { Output of } \\
\text { BOOST } \\
(\text { V) }\end{array}$ \\
\hline 9 & 4 & 15 & 31.96 & 14.6 & 28.9 \\
\hline 9 & 7 & 15 & 31.95 & 14.7 & 27.6 \\
\hline 9 & 9 & No operation & 34.32 & Standstill & 27.8 \\
\hline
\end{tabular}

Table 3Comparison of simulation and hardware results for various voltages

Table 3 shows the comparison of simulation and hardware results for various input voltages. Table 4 gives the output voltage and current for various load.

Table 4Comparison of voltage and current by varying the resistive load

\section{Conclusion}

\begin{tabular}{|l|l|l|}
\hline $\begin{array}{l}\text { RESISTIVE } \\
\text { LOAD(ohm) }\end{array}$ & $\begin{array}{l}\text { OUTPUT } \\
\text { VOLTAGE(V) }\end{array}$ & $\begin{array}{l}\text { OUTPUT } \\
\text { CURRENT(A) }\end{array}$ \\
\hline 10 & 28.9 & 3.1 \\
\hline 20 & 30.1 & 1.14 \\
\hline 30 & 30.94 & 1.031 \\
\hline 40 & 31.34 & 0.783 \\
\hline 50 & 31.59 & 0.63 \\
\hline 60 & 31.76 & 0.52 \\
\hline
\end{tabular}

In realistic conditions due to partial shading and pollution the output of PV system gets reduced even if perfect components are used for its design. This paper introduces a module level DC/DC SEPIC converter which is active only when there is a difference between the substrings or modules output power exist. The operating time of the converter is less and the system reliability increases by connecting such converters in PV system. As the power difference is alone fed to the converter a low cost, low efficiency converter can be used to eliminate the effects of partial shading in PV systems. The simulated result of the converter is compared with the hardware results. Maximum performance of the system is found irrespective of the changes in physical condition.

\section{References}

G.R. Walker, P.C. Sernia, “Cascaded DC-DC Converter Connection for Photovoltaic Modules,” IEEE Trans. On Power Electronics, vol. 19, no. 4, July 2004, pp. 1130-1139

B J. Cao, N. Schofield, A. Emadi, "Battery Balancing Methods: A Comprehensive Review," in proc. IEEE Vehicle Power and Propulsion Conference, Harbin, China, September 3-5, 2008, pp. 1-6

S.B. Kjaer, J.K. Pedersen, F. Blaabjerg, "A Review of Single-Phase Grid-Connected Inverters for Photovoltaic Modules,” IEEE Trans. On Industry Applications, vol. 41, no. 5, September/October 2005, pp. 1292-1306

H.J. Bergveld, D. Büthker, C. Castello, T.S. Doorn, A. de Jong, R.van Otten, K. de Waal, "Module-level DC/DC Conversion for Photovoltaic Systems," in Proc. IEEE International Telecommunications Energy Conference, Amsterdam, the Netherlands, October 9-13, 2011, pp. 1-9.

Koutroulis E, Kalaitzakis K, Voulgaris NC "Development of a microcontroller-based photovoltaic maximum power point tracking control system,” IEEE Trans Power Electron 16 (1):46-54, 2001

Tian H, Mancilla-David F, Ellis K, Muljadi E, Jenkins P "Determination of the optimal configuration for a photovoltaic array depending on the shading condition," Solar Energy 95:1-12, 2013

S. Choi, et al., "Analysis, design and experimental results of a floating-output interleaved input boost-derived DC-DC high-gain transformer-less converter," IET Power Electron., vol. 4, iss. 1, pp. 168-180, Jan. 2011.

M.H. Taghvaee, et al., "A current and future study on non-isolated DC-DC converters for photovoltaic applications," Renewable and Sustainable Energy Reviews, vol. 17, pp. 216-227, Oct. 2012.

F. Garcia, et al., "Modeling and Control Design of the Interleaved Double Dual Boost Converter, " IEEE Trans. Ind. Electron. vol. 60, no. 8, Aug. 2013.

M. G. Simoes and N. N. Franceschetti, "Fuzzy optimization based control of a solar array system," IEEE Proc.Electr. Power Appl., vol. 146, no. 5, pp. 552-558, Sep. 1999.

T. Esram, and P. L. Chapman, "Comparison of Photovoltaic Array Maximum Power Point Tracking Techniques, " IEEE Trans. Energy Conversion, vol. 22, no. 2, pp. 439-448, Jun. 2007.

K.H. Hussein, et al., "Maximum photovoltaic power tracking: an algorithm for rapidly changing atmospheric conditions, ” IEE Proc.-Gener. Trans. Distrib., vol. 142, no. 1, pp 59-64, Jan. 1995. 
Muthubalaji, S., Kareem, M. A., Karuppiah, N., \& Sugirtha, M. G. (2017, December). “An enhanced analysis of two diode model PV module under various weather conditions". In 2017 IEEE International Conference on Circuits and Systems (ICCS) (pp. 162-167). IEEE. 